\title{
Az ENSZ minősített városi kutató- mentő csapatai elektronikus adatgyüjtési feladatainak végrehajtása kiterjedt katasztrófa kárterületen az INSARAG ICMS használatával
}

\section{The Execution of the Electronic Data Collection Tasks Made by the UN-classified USAR Teams on Extended Disaster Area Using the INSARAG ICMS}

Az ENSZ minősített városi kutató-mentő csapatai elsődlegesen a földrengés-katasztrófák helyszínén végrehajtandó speciális feladatokra készülnek. A katasztrófa típusából és a rengés erősségéből adódóan ez legtöbbször egy kiterjedt kárhelyszínt fog jelenteni. Ezen a romosodott és sokszor életveszélyes színtéren kell eltűnt, beszorult személyeket megtalálni és megmenteni, sokszor kutya, akusztikus kereső vagy mentőkamera segítségével. A helyi erők képességeinek megerősítésére számos nemzetközi mentöcsapat érkezhet, és a beavatkozó nemzeti és nemzetközi állománynak a hatékonyság érdekében együtt kell müködnie. A jövőben a világ számos pontján a közös platform erre várhatóan a Nemzetközi Kutatási és Mentési Tanácsadó Csoport (INSARAG) Irányító és Koordinációs Rendszer (International Search and Rescue Advisory Group Coordination and Management System - ICMS) használata lesz, amellyel a koordinációs és irányítási feladatok szakszerűen megvalósíthatók.

Kulcsszavak: kutató-mentő, elektronikus adatgyüjtés, ICMS 
The United Nations (UN)-classified urban search and rescue teams are primarily prepared for special tasks to be carried out at the scene of earthquake disasters. Due to the type of the disaster and the strength of the earthquake, this will most often mean an extensive site of damage. In this dilapidated and most often life-threatening arena, missing and trapped people must be found and rescued, often with the help of a dog, an acoustic device or a search camera. A number of international rescue teams may be deployed to strengthen the capabilities of local forces, and national and international intervening personnel must work together to be effective. In the future, these management and coordination tasks can be professionally solved, and the common platform for this will be the ICMS system in many parts of the world.

\section{Keywords: search and rescue, electronic data collection, ICMS}

\section{Bevezetés}

Egy kiterjedt katasztrófa helyszínén, különösen a mentések végrehajtásának időszakában számos nemzeti és nemzetközi egység végezheti egyszerre a feladatokat. Ezek az esemény típusától függően eltérhetnek, de minden esetben az emberi életek mentése fog elsődlegességet élvezni. Az operatív feladatok során számos szereplő van jelen, és nagyon nehéz a hatékony koordinációt megvalósítani. Ezt számos múltbeli esemény és az általuk megszerzett tapasztalat igazolja. Idetartozik például az 1985-ös mexikóvárosi ${ }^{2}$ és az 1988-as örményországi ${ }^{3}$ földrengés, amelyek hatására az ENSZ Nemzetközi Kutatási és Mentési Tanácsadó Csoport (International Search and Rescue Advisory Group - INSARAG) létrejött. A világszervezet égisze alatt három fö régióban (Afrika/Európa/Közel-keleti régió, Amerikai régió, Ázsia/Csendes-óceáni régió) több mint 90 tagállam hangolja össze jelenleg földrengések ellen a városi kutatási-mentési tevékenységét, valamint fejleszti a jövőbeli képességeit a 2020-2025-ös időszak közös Fejlődő Rugalmas Támogatás (Advancing Flexible Assistance) programja segítségével. ${ }^{4}$ Ezt a bonyolult és komplex tevékenységet rendkívül nehéz megvalósítani, de a minősített városi kutató-mentő csapatok az eltelt 30 év folyamatos tapasztalatfeldolgozása és szakmai innovációja miatt korszerüen képesek rá. Éppen ezért a cikk célja, hogy a rendelkezésre álló dokumentációból kutassa a minősített mentőcsapatoknál alkalmazott elektronikus rendszereket, valamint egy nagy adatbevitelü gyakorlat elemzésével vizsgálja a hatékonyságot és a hazai alkalmazás lehetőségét. Ez különösen fontos lehet a későbbiekben a hazai tömeges vagy kiterjedt katasztrófa-káresemények felszámolásánál.

Az ENSZ INSARAG minősített mentőcsapatok tevékenysége során nem kevesebbet kell elérni, mint azt, hogy a számos tagország és szervezet közel azonos szervezeti formában és metodikával, az INSARAG-irányelveknek megfelelően legyen képes egymással együttmüködni. A helyzetet bonyolítja, hogy a közös cél érdekében át

\footnotetext{
David Adler: The Mexico City earthquake, 30 years on: have the lessons been forgotten? The Guardian, 2015. szeptember 18.

BBC: In pictures: $25^{\text {th }}$ anniversary of Armenian earthquake. BBC News, 2013.

4 3rd INSARAG Global Meeting 2020 Concept Note-INSARAG Session on Strategic Objectives 2020-2025. INSARAG, 2019.
} 
kell hidalni a világ számos országában meglévő társadalmi, kulturális, nemi és vallási helyzetekből adódó különbségeket, és mellérendelt szerepkörben hatékonyan meg kell valósítani az irányítási és vezetési, valamint a koordinációs, kommunikációs és diplomáciai feladatokat. Ezek megvalósítása - a nehézségükből fakadóan - az operatív katasztrófavédelmi szakmai tevékenység csúcsát jelenti, különösen a mentőcsapatok vezetésitörzs-komponensét illetően. Itt ugyanis a fizikai, pszichikai és egészségügyi alkalmasság mellett követelmény a katasztrófavédelmi szakmai ismeretek magas szintủ és kreatív, improvizatív alkalmazásának képessége. Ezeken felül további követelmény a magas szintủ angol nyelvtudás, mivel ennek hiányában a más mentőszervezetekkel és az operatív irányítást végző helyi hatóságokkal a kommunikáció nem lehetséges. Elvárás továbbá az informatikai jártasság és a Virtuális Helyszíni Műveleti Koordinációs Központ (Virtual On-Site Operations Coordination Centre - VOSOCC) hozzáférés, a hatályos irányelvek ismerete és alkalmazni tudása, továbbá vizsga tétele az Egyesült Nemzetek Szervezete Védelmi és Biztonsági Hivatalának (United Nations Department of Safety and Security - UNDSS) „Légy Biztonságban!” (BSafe) ${ }^{5}$ biztonsági tanfolyamából. ${ }^{6}$

Az ENSZ INSARAG rendszere annak érdekében, hogy minél magasabb szinten és hatékonyan tudjon müködni, folyamatosan fejleszti minden szakterületét, és kihasználja az egyes tagországok különleges képességeit és erősségeit a feladatainak megvalósításához. Az 1990-es évektől egészen 2015-ig a kárterületi adatgyüjtések során elsődlegesen a papíralapú ürlapok használata volt meghatározó. Ezt követően a német Szövetségi Müszaki Segélyszolgálat (Technisches Hilfswerk - THW) szakembere, Peter Wolff javaslatára a mentöcsapatok a Kobo Adatgyüjtö Rendszer (Kobo Toolbox - KT) használatára tértek át, és célul tüzték ki az egységes elektronikus adatgyüjtést, ${ }^{7}$ hogy közöttük a koordináció minél hatékonyabban megvalósulhasson. Wolff 2013 óta tölti be az ENSZ INSARAG Információs munkacsoport (UN INSARAG Information Management Working Group - IMWG) elnöki tisztjét.

Az INSARAG-mentőcsapatok a kárterületi elektronikus adatgyüjtési és adatfeldolgozási feladatokból a minősítésük során sikeres vizsgát kell hogy tegyenek. ${ }^{8}$ Az egységek ezt teljesítették és rendszeresen használták a KT-t gyakorlatok és éles helyzetek alkalmával. A KT rendkívül hatékony eszköz volt, és azt bizonyította, hogy az elektronikusan végzett adatgyüjtési és adatkezelési, valamint a vezetési törzsek irányába történő jelentési idők a papíralaphoz képest a töredékére csökkenthetők. A felgyorsult folyamatoknak köszönhetően a mentésre fordítható idő nagymértékben megnövekedett, amely a kárterületen a „100 órás szabály" figyelembevétele miatt különösen fontossá vált. INSARAG szakmailag elfogadott szabály ugyanis, hogy ritka kivételektől eltekintve (például bajba jutott ország külön kérése) nagyságrendileg 100 óra az, ameddig a romosodott kárterületen a mentőcsapatok keresési tevékenységet

BSafe: A „Be safe!”, „Légy biztonságban!” kifejezés rövidítése, szlengesítése. Tartalmát tekintve ez egy online védelmi és biztonsági kurzus, amelynek elvégzése az ENSZ személyi állományának kötelező, a külföldi humanitárius missziókon részt vevő személyeknek pedig erősen javasolt.

6 UN: „BSAFE” - United Nations Department of Safety and Security Online courses website. 2020.

7 Hábermayer Tamás: A Kobo Toolbox program alkalmazása az ENSZ INSARAG minősített mentőcsoportok kiterjedt kárterület felmérése során. Hadmérnök, 12. (2017), 2. 127.

8 "INSARAG External Classification Handbook, Volume II Manual C, Annex A - The IEC/R checklist" - UN INSARAG website, 2019. 47. 11. 
folytatnak. Ezután az idő után ugyanis egy felnőtt személynek rendkívül alacsony a túlélési esélye. Sajnos, gyermekek esetén ezen idő jelentősen kevesebb is lehet.

A KT használata alatt viszont a fejlődés nem állt meg, és 2018-ban a Romániában tartott INSARAG csapatvezetői értekezleten az IMWG már arról számolt be, hogy a KT helyét 2020-tól az annál már jóval fejlettebb, a városi kutatás-mentési szaktevékenységhez az Environmental Systems Research Institute (ESRI) cég által fejlesztett ICMS-rendszer veszi át.

\section{Az ICMS-rendszer elemeinek bemutatása}

Az ICMS a városi kutatás-mentési feladatok ellátásához készített számítógépes támogatói rendszer, amelyet adatgyüjtésre és -feldolgozásra szakosodott informatikusok készítettek céleszköznek az INSARAG minősített mentőcsapatok számára. A szakemberek az ICMS elkészítéséhez a korábbi tapasztalatokra alapozva négy nagy felhasználói csoportot vettek figyelembe, az INSARAG-irányelvek szerinti szervezeti müködésre alapozva. Így különbontották a Fogadási/Indulási Központ (Reception/ Departure Center - RDC), Városi Kutató-Mentő Koordinációs Egység (Urban Search and Rescue Coordination Cell - UCC), gyakorlatszervező (Exercise Control - EXCON), mentőcsapat (Team) csoportokat, akik a funkciójuknak megfelelő mélységig kaptak hozzáférést és szoftverhasználati lehetőségeket. Számukra külön-külön felhasználói kézikönyvek készültek, amelyeket a korábban felsorolt csoportoknak címezve, célzott, külön tematika szerint állítottak össze. ${ }^{9}$

A könyvek az ICMS szempontjából lényeges következő fő tartalmakat mutatják be: a UCC működése, az RDC, a csapatvezetés és az EXCON feladatai, a munkamenetek folyamata, az INSARAG ICMS központi csomópont müködése, az elemző és értékelő tábla (dashboard) használata, továbbá a UCC-applikációk és az ArcGIS Explorer, Survey123 programok alapvető funkciói. Lényeges továbbá, hogy a kárhelyszíni fényképek adattömörítéses felhasználása és megosztása okán ismerni és alkalmazni kell tudni az ENSZ Globális Hálózati Képtovábbító és Alkalmazkodó Rendszerét (Adaptive System for Image Communication over Global Networks - UN ASIGN), ${ }^{10}$ mivel a mentőcsapatok tapasztalata az, hogy a kiterjedt katasztrófa-káresemények helyszínén az internet csak korlátozottan használható. A kommunikációs rendszerek sérüléséből, megsemmisüléséből vagy a terheltségéből adódóan (esetleg a mentőcsapatok a feladatot csak müholdas hozzáféréssel tudják ezt biztosítani, amely rendkívül drága) általában csak korlátozott és alacsony sávszélesség válik elérhetővé. Emiatt a nagyméretű fájlok, adatok továbbítása nehézségekbe ütközik, de ugyanakkor fontos lehet a beavatkozások szempontjából. A UN ASIGN program segítségével a fényképek fájlmérete nagyságrendekkel csökkenthető és a cél érdekében a szakszerü kezekben gyorsan megosztható.

A felsorolásból látható, hogy az ICMS-rendszer nem egyetlen programból áll, hanem gondosan összeválogatott programok összességéből. E szoftverek sokszor

\footnotetext{
INSARAG: RDC, UCC, EXCON, Team Guide. INSARAG, 2020.

10 UN-ASIGN website: https://asign.cern.ch
} 
külön-külön is használhatók egyes részfeladatok végzésére, de a megfelelő szakmai ismeretek birtokában egy komplex múveletirányító és információs elemző-értékelő felületté állnak össze.

Ezen keresztül az egymásnak mellérendelt nemzetközi mentőcsapatok munkája rendkívüli hatékonysággal az ENSZ szakemberei által elektronikusan irányítható. A beérkezett és feldolgozott adatokat az elemző és értékelő táblán különösebb beavatkozás nélkül azonnal feldolgozzák, és a rendszer használói számára azok közvetlenül elérhetővé válnak. A megfelelő hozzáférés birtokában így a világ bármely pontján is tartózkodik a bevont szakértő, azonnali és hiteles tájékoztatást kap a folyamatban lévő feladatokról, a koordináció megvalósulásáról. A szoftverek éles helyzetben történő működőképesség-tesztelése is megtörtént már a 2020 -as bejrúti robbanás ${ }^{11}$ során. A káresemény múveleti és koordinációs feladatainak végrehajtása során az ICMS-rendszer 13 nemzetközi szintű mentőcsapat és a helyi erők tevékenységét fogta össze, a tapasztalatokat pedig nyilvánosan is elérhető videókonferencián megosztották az INSARAG weboldalán. ${ }^{12}$

\section{Az ICMS központi csomópont használati lehetőségei és a munkamenet folyamata}

A jelentős, nagy erősségü földrengés-katasztrófák bekövetkezésekor az ENSZ nemzetközi szakértői közössége a Globális Katasztrófa Elörejelző és Koordinációs rendszer (Global Disaster Alerting Coordination System - GDACS) VOSOCC felületét használva tud soron kívül tájékozódni a katasztrófák (disasters) menüpont kiválasztásával (1. ábra). ${ }^{13}$ Ezen pontban az adott katasztrófaesemény kiválasztását követően további fontos információkhoz lehet hozzáférni. Például: általános helyzet áttekintése (situation overview), a nemzetközi segítségkérés állapota (status of request of assistance), múveleti környezet áttekintése (operational environment), mentési feladatok koordinációja (response coordination). Itt található meg a katasztrófához kapcsolt ICMS-link elérhetősége, amelyen keresztül a rendszer aktív felületét elérhetjük. A link kiválasztásával továbbhaladva lehet eljutni az ICMS központi csomópontig. Ez már viszont egy védett és nem nyilvános felület, amelynek tartalmát csak az arra jogosult és felkészített szakemberek használhatják.

Idetartoznak az ENSZ Humanitárius Ügyek Koordinációs Hivatala (United Nations Office for the Coordination of Humanitarian Affairs - UN OCHA), az Információs Munkacsoport tagjai, továbbá a különösen fontos humanitárius személyek (very important person - VIP) és a nemzetközi minősített mentőcsapatok vezetése. Részükre biztosítottak a belépéshez szükséges adatok. A csomópontba történő bejelentkezést követően lehet hozzáférni a program fő funkcióihoz, amelyen keresztül a szakfeladatok

Michael Safi et alii: Beirut blast: a night of horror, captured by its victims. The Guardian, 2020.

12 "INSARAG Technical After Action Review following Beirut port explosions 4-5 November 2020" - UN INSARAG website, 2020.

13 Hartner Péter - Hábermayer Tamás - Muhoray Árpád: A Globális Katasztrófa Előrejelző és Koordinációs, valamint a Közösségi Veszélyhelyzeti Kommunikációs és Információs Rendszerek bemutatása. Hadmérnök, 13. (2018), 3. 206. 
elvégezhetők. A minősített mentőcsapatok külön felhasználónevet és ahhoz tartozó jogosultságokat kaptak a csapatra és a városi kutatás-mentési koordinációs egységre.

Ebből is látszik, hogy a mentőcsapatok közös koordinációs egysége rendkívüli fontosságú a közös müveletek szempontjából. Éppen ezért az INSARAG-irányelvek előírják, hogy minden minősített mentőcsapatnak kötelezően képesnek kell lennie arra, hogy szakértő személyzetet tudjon biztosítani a nemzetközi szintü koordinációs egységbe. Közepes mentőcsapatok esetén ez 2 , nehéz mentőcsapatok esetén 4 fö kiképzett személyzetet jelent a saját állományból. E személyek jellemzően a mentőcsapatok legmagasabban képzett és legjobb képességú állományából kerülnek ki, amely a csapat alapképességeit, feladatellátását megnehezítheti.

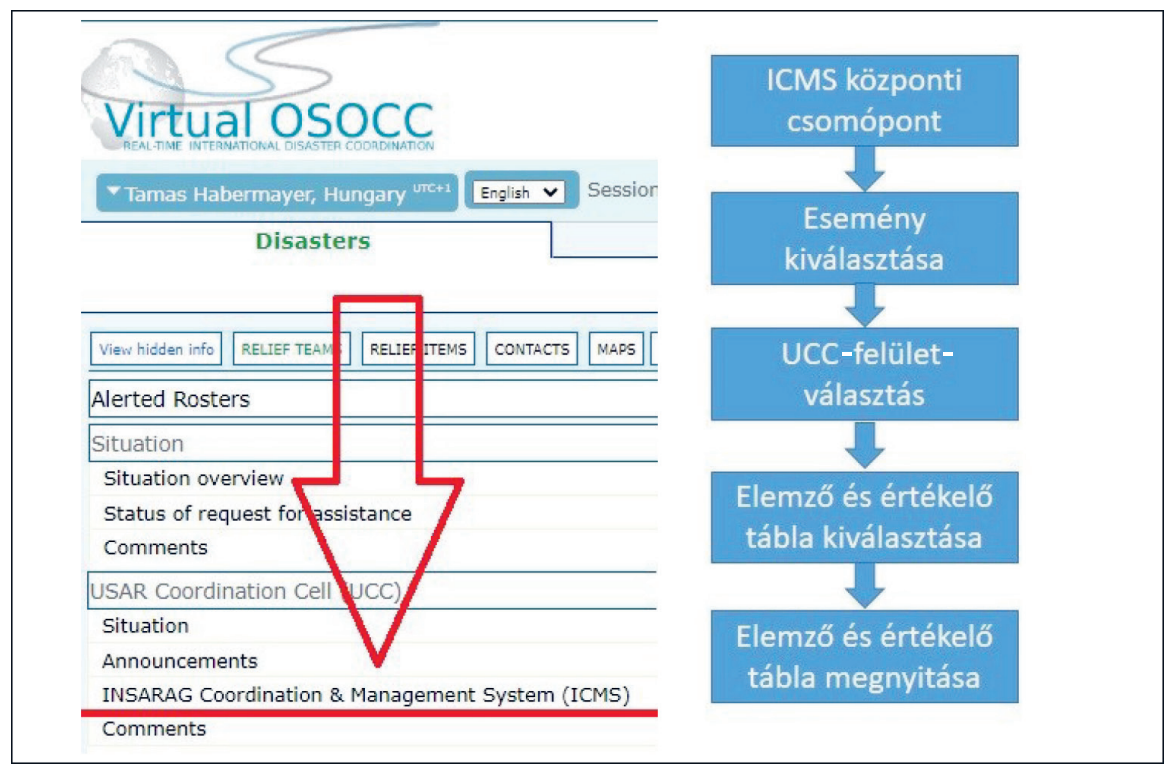

1. ábra

Az ICMS-rendszer Virtual OSOCC-elérése és a munkamenet folyamata

Forrás: a szerző szerkesztése

A csapat részére biztosított jogosultságok a kárhelyszíni operatív feladatok végzését (elektronikus adatgyüjtés és jelentések megtétele, koordinációs feladatok) és a legfontosabb információk megtekintésének lehetőségét biztosítják, elsősorban az elemző-értékelő tábla összegző felülete, valamint a Survey123, UN Asign és ArcExplorer programok segítségével. A UCC-hozzáférés ennél jóval több jogosultságot biztosít. Segítségével a kijelölt állomány képes a szektorizációs feladatok elvégzésére, amellyel a kárterület részekre bontható (2. ábra). ${ }^{14}$

14 INSARAG External Classification Handbook, Volume II Manual C, Annex A - The IEC/R checklist - UN INSARAG website, 2019. 24. 


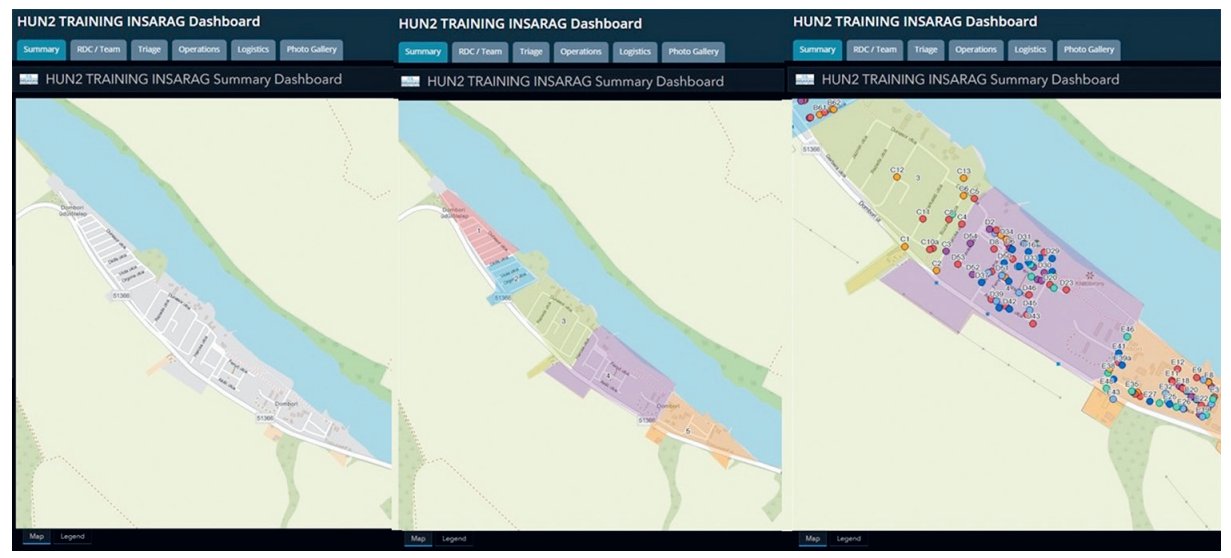

2. ábra

ICMS-szektorizáció folyamata lépésenként balról jobbra haladva

Forrás: a szerző szerkesztése

Ezt követően a mentőcsapatok már elektronikus felületen is látják a számukra meghatározott részterületeket, amelyen az operatív felderítési és mentési feladatokat végre fogják hajtani. Az ICMS központi csomópontból elérhető az UCC-applikáció, amelyben számos lehetőség nyílik a múveleti térképfelületen történő adatok rögzítésére és megjelenítésére. Az okos szerkesztő (smart editor) funkció segítségével kijelölhetőek az eseményre vonatkozó határvonalak, szektorok, amelyek szükség szerint egyszerüen frissíthetők, hozzájuk kiegészítő adatok (például területre vonatkozó biztonsági szabályok) rögzíthetők. Lehetőség van a bevitt adatok kapcsán szürések végrehajtására a szürő (filter) opciók választásával, amelyek révén a munkatérképen csak az általunk feltételként megadott adatok jelennek meg. Ez a funkció jelentősen megkönnyíti például az egyes káresemények, kárhelyszínek keresését, vagy meggyorsítja az egyes szektorokra vonatkozó tevékenység megjelenítését. A munkatérkép használata során 24 alaptérkép közül választhatunk (például müholdképes, topográfiai, éjszakai, hibrid, nova), amelyet az éppen aktuális feladathoz vagy időszakhoz lehet igazítani. Ezeken felül további adatok (például Url, fájlok csatolása) felvitelét és a felvitt rétegek kezelését is elvégezhetjük.

Az ICMS központi csomópontból indulva a következő program, amelyet a UCC állománya használ az a UCC minőségbiztosítás (quality assurance - QA) applikáció. E szoftver használatának bevezetését az IMWG elsősorban a múltbeli éles káresemények tapasztalatai miatt vezette be. Számos alkalommal fordult ugyanis elő, hogy a kárterületen gyüjtött adatok hibásak vagy nem értelmezhetők voltak és emiatt a szakmai döntéshozatal nehézségekbe ütközött (vagy egyáltalán nem lehetett racionális döntést hozni belölük). Ez komoly problémákhoz vezetett, hiszen a kárterületen a logisztikai és erőforrásbeli képességek korlátozott volta miatt a hibás döntések számtalan alkalommal vezettek konfliktushelyzethez. Ezen események kiküszöbölését célozza a QA-rendszer. Segítségével ugyanis csak azon elektronikusan gyűjtött adatok kerülhetnek be a valós müveleti adatok közé, amelyeket az arra felhatalmazott szakmai 
személyzet (elsősorban csapatvezető, csapatvezető-helyettes, UCC állománya) leellenőrzött és névvel, dátummal, elektronikus aláirásával jóváhagyott. Ez tulajdonképpen a mentőcsapatok vezetőségének felelősségét hangsúlyozza, és globális szinten nagymértékben emeli az adatpontosságot, fokozza a múveleti hatékonyságot. Amennyiben szakmailag képzett személy felelősséggel elvégzi ezen ellenőrzést, akkor nem, vagy csak rendkívül kis eséllyel következhet be hiba a rendszerben.

A Survey123 program a következő része az ICMS központi oldalnak. Ez a szoftver az elektronikus ürlapok használatával az INSARAG-elvek szerinti kárterületi adatgyűjtést tesz lehetővé, például mentőcsapatképesség-adatlap (team factsheet), kárterületi triázs adatlap (worksite triage form), kárhelyszínjelentés-adatlap (worksite report form), erőforrás-igénylés (resource request), mentőcsapat-levonulási adatlap (team demobilisation form) kitöltésével (3. ábra).

Az ICMS szempontjából ez a rész kiemelten fontos a minősített mentőcsapatok beavatkozói állománya számára, akik a rendszerben e kárhelyszíni adatok rögzítését végzik.

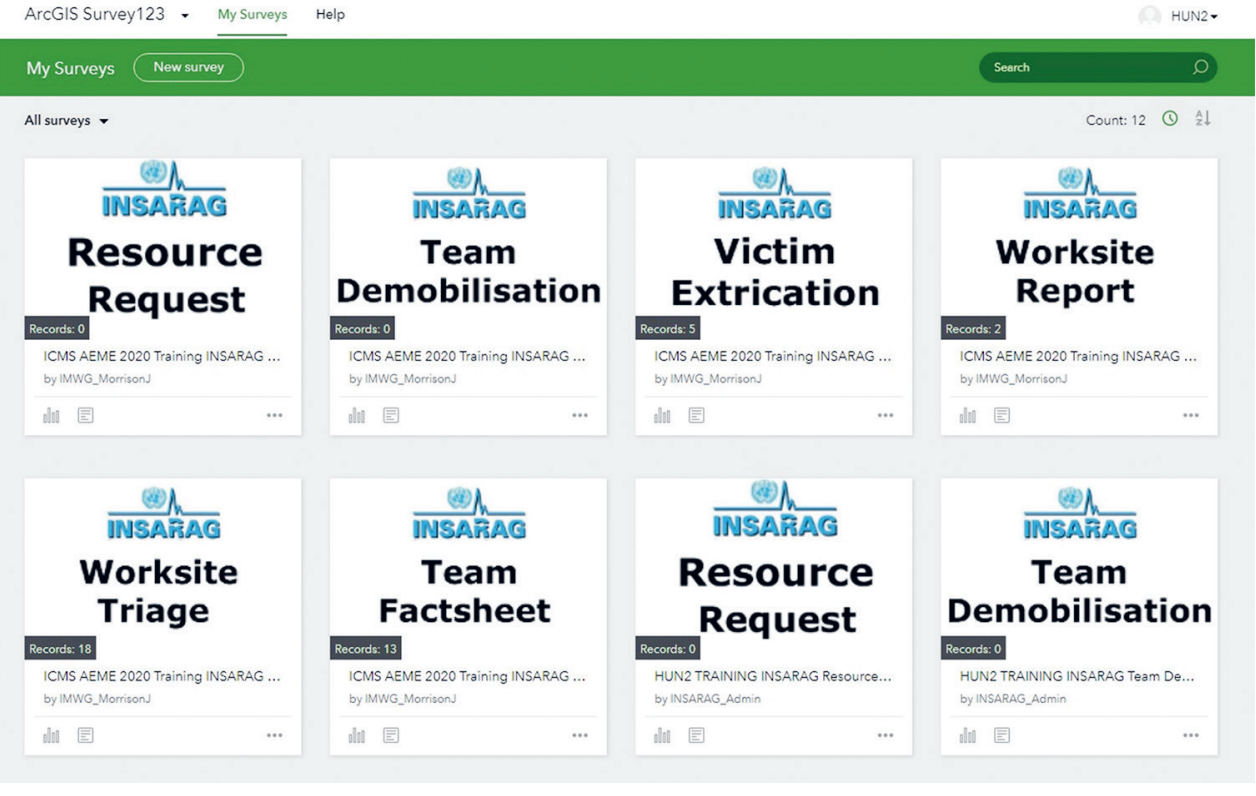

3. ábra

ICMS Survey123 program felülete az elektronikus ürlapokkal

Forrás: a szerző szerkesztése

Az ICMS-rendszer ürlapkitöltő applikációjának nagy előnye, hogy automatikusan kihasználja az elektronikus eszközök helymeghatározási képességét, így az adatok rögzítését végző állomány a saját álláspontját a használt eszközétől függően, de akár másodpercek alatt is képes kellő pontossággal rögzíteni. Ez alapján a program képes azt azonnal a szektorokban elhelyezni, és ha van, akkor utcanevet és címet is rögzíteni hozzá (4. ábra). 


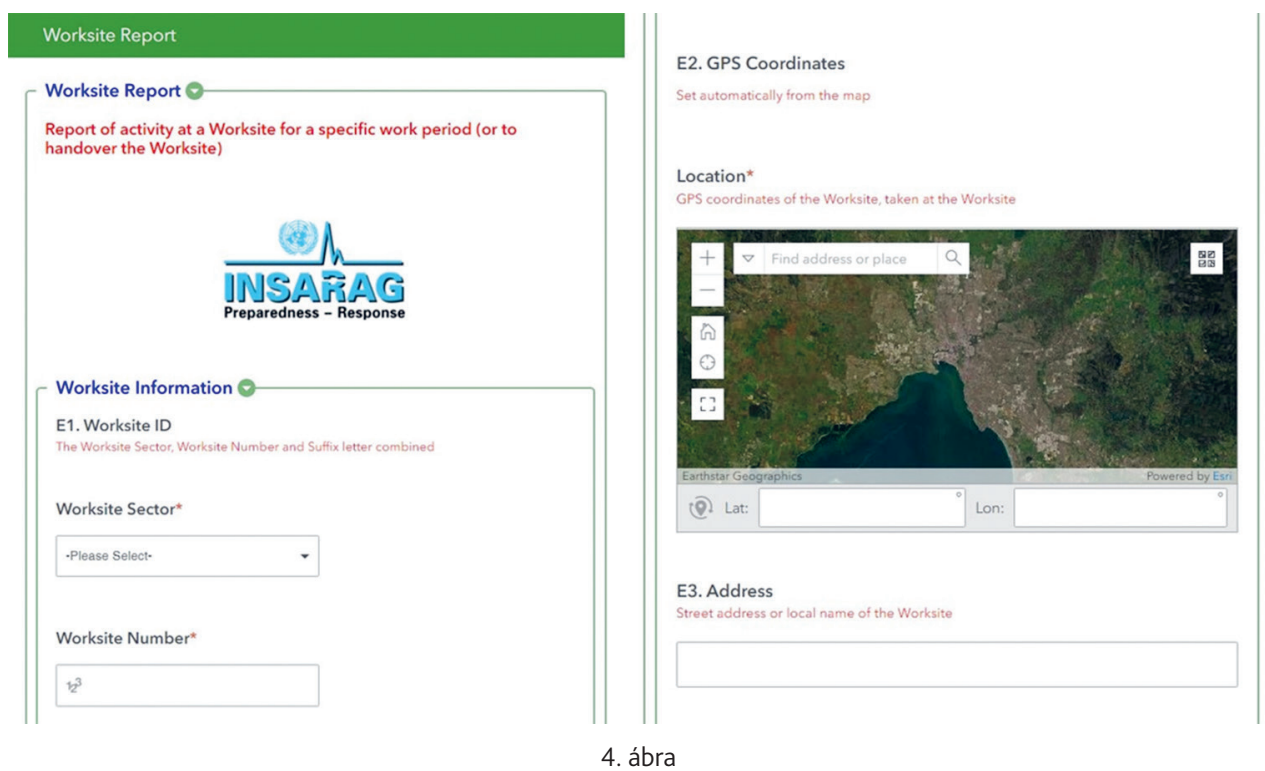

ICMS Survey123 program felülete az elektronikus ürlapokkal

Forrás: a szerző szerkesztése

\section{Az ICMS-rendszerben végrehajtott gyakorlat elemzése}

Az ICMS-rendszer részeként a mentőcsapatok rendelkeznek egy önállótréning-felülettel is, amely tulajdonképpen a központi csomópont müködését modellezi. Segítségével az éles alkalmazáshoz szükséges összes funkció kipróbálható, a gyakorlatokra kijelölt kárhelyszíneken valós adatok gyüjthetők. Ennek tudatában az INSARAG-egységek közül már sokan hajtottak végre önálló gyakorlatot. A következőkben egy gyakorlat - kiterjedt kárterületet imitáló tréning helyszínén történt - adatait és tapasztalatait összesítjük, adatvédelmi okok miatt anonim módon.

A gyakorlatot 2020. 09. 04. 04:00 - 2020. 09. 04. 07:00 időszak között hajtotta végre egy képzett, minősített mentőcsapat. A feltételezés szerint egy folyópart melletti üdülöövezetben következett be a nagy erejű földrengés. A katasztrófa hatására az épületek jelentős része összedőlt vagy romosodott, így szükségessé vált a nemzetközi segítség kérése a bajba jutottak mentéséhez. Az elgondolás szerint 8 mentőcsapat ( 5 valós helyszíni és 3 virtuális) egységei dolgoztak együtt a romosodott terület felmérésén. Részelemként a UCC is valós müködésbe lépett és végrehajtotta a szektorizációt, amely során 5 szektort határozott meg (A, B, C, D, E). A felmérést a kijelölt erők a számukra meghatározott területek szerint 5 párban, 10 fö részvételével hajtották végre, és a három óra leforgása alatt a 32,69 hektárnyi terület 30 utcájában mindösszesen 245 egyedi kárhelyszínt mértek fel. Az ilyen eseményeknél 
használt INSARAG adatfelvételi ürlap ${ }^{15} 29$ kitöltendő adatmezőt (például kárhelyszín azonosítója, kárterület határai, fénykép, biztonsági szabályok, GPS-koordináta stb.) tartalmaz, amelyek mindegyike fontos információ a minősített mentőcsapatok közötti koordináció megvalósításához. Az adatokat egy táblázatban összefoglalva a következő eredmények mutatkoztak:

1. táblázat

ICMS-gyakorlat tapasztalatok

Forrás: a szerző szerkesztése

\begin{tabular}{|c|c|c|c|}
\hline & Összesen & Mentőcsapatonként & 1 före eső \\
\hline Eltelt idő (percben) & \multicolumn{3}{|c|}{180} \\
\hline Helyszíni mentőcsapatok valós száma (db) & \multicolumn{3}{|c|}{5} \\
\hline Helyszíni mentőcsapatok valós állománya (fő) & \multicolumn{3}{|c|}{10} \\
\hline Terület mérete $\left(\mathrm{m}^{2}\right)$ & 326900 & 65380 & 32690 \\
\hline Utca (db) & 30 & 6 & 3 \\
\hline Kárhelyszínek száma (db) & 245 & 49 & 24,5 \\
\hline Kárhelyszíni triázs adatmező szám (db) & \multicolumn{3}{|c|}{29} \\
\hline Összesen kitöltött adatmezők száma (db) & 7105 & 1421 & 710,5 \\
\hline 1 adatmező kitöltésére fordított átlagos idő & - & 0,13 perc & 0,25 perc \\
\hline A végrehajtás során javított adatmező (db) & 8 & 4 & 2 \\
\hline A végrehajtás során fellépő szoftverhiba (db) & 0 & 0 & 0 \\
\hline A végrehajtás során fellépő hardverhiba (db) & 0 & 0 & 0 \\
\hline $\begin{array}{l}1 \text { kárhelyszín triázs adatlapon történő átlagos feldol- } \\
\text { gozási ideje elektronikusan }\end{array}$ & - & 3,67 perc & 7,34 perc \\
\hline 1 kárhelyszín kitöltése papíralapon ${ }^{16}$ & - & - & 8,4 perc \\
\hline $\begin{array}{l}\text { Az adatok alapján egy } 10 \text { ezer } \mathrm{m}^{2} \text { vidékies övezetre } \\
\text { valószínűsíthető kárhelyszínek száma mentőcsapa- } \\
\text { tonként és személyenként }(\mathrm{db})\end{array}$ & 7,49 & 7,49 & 3,74 \\
\hline $\begin{array}{l}\text { Az adatok alapján egy } 10 \text { ezer } \mathrm{m}^{2} \text { vidékies övezetre } \\
\text { valószínüsíthető kárhelyszínek felderítési ideje } 1 \text { men- } \\
\text { tőcsapat ( } 2 \text { fös) esetében }\end{array}$ & \multicolumn{3}{|c|}{27,48 perc } \\
\hline
\end{tabular}

Az adatok elemzése során több megállapítást is tehetünk. Az első, hogy a bevitt összes adatmezőből (7105) mindössze 8 esetben kellett - jellemzően értelmezésbeli okok miatt - javítani. Ez alapján a hibázás százalékos arányai - 99,9\% helyes és 0,1\% helytelen bevitel. Ez kiemelkedő pontosságot eredményez, amelyhez még hozzájárul, hogy az elektronikus rögzítést követően ugyanazon adatokat használják a mentőcsapatok és a UCC is.

Ezen túl a hatékonyságot tovább fokozza és a beavatkozási időt is rövidíti, hogy a papíralaphoz képest elegendő az egyszeri bevitel. Ezt követően az adatok az elektronikus rendszerben elérhetővé válnak az azonnali, többcélú használatra. Így már viszont nem szükséges a korábban „megszokott” további kiegészítő tevékenységek

15 Worksite Triage Form - Kárhelyszíni triázs adatlap.

16 A kitöltés 10 fő képzett szakember segítségével, időre méréssel történt. 
(például a papíradatok lemásolása, táblázatokba szerkesztése, fényképeken küldése stb.) végzése. Mindez jelentős mértékben optimalizálja a különböző szervezetek közötti kommunikációs és koordinációs feladatok végrehajtását, és magasabb színvonalú mentési tevékenységet tesz lehetővé a kiterjedt katasztrófa-kárterületek helyszínén.

\section{Következtetések}

Az ENSZ INSARAG szakemberei a megszerzett kollektív tudás és tapasztalat kihasználásával szinte az első szervezetek között kötelezték el magukat az elektronikus informatikai rendszerek használata mellett. Ezt jelzi, hogy a szaktudás minden mentőcsapat esetében alapvető, ellenőrizendő minősítési kritérium. Ha valamely csapat nem képes a használatára, akkor nem szerezhet minősítést.

Kezdetben a szakemberek a KT-programot használták, amely rövid távon (20172020) hatékonynak bizonyult. Segítségével a nemzetközi minősített mentőcsapatok tagjai elsajátították a kárterületi elektronikus adatgyűjtés alapvető fogásait, és segítségükkel jelentősen képesek voltak redukálni az egyes katasztrófavédelmi operatív müveletek végrehajtásához, valamint a döntéshozatalhoz szükséges időt.

A KT-programot 2021. évtől a jelenlegi ICMS-rendszer váltja. A célhoz kötött professzionális szoftverrendszer képes volt jelentősen tovább fokozni a hatékonyságot. Az elemző és értékelő tábla, a központi csomópont és a Survey123 előnyeit, különösen a koordinátaalapú virtuális megjelenítést és az összegző felületet a nemzetközi szervezetek a koordinációs feladatokhoz folyamatosan felhasználják.

Magyarországon egyedül a HUNOR és HUSZÁR mentőcsapatok tagjai ismerik az ICMS-rendszer használatát, és képesek annak éles használatára nemzetközi környezetben is. Kiterjedt és tömeges katasztrófa-káresemények évente több alkalommal is bekövetkeznek Magyarországon, felszámolásuk nehézkes és időigényes feladat. Az ENSZ INSARAG és az ICMS-rendszer példáját látva viszont érdemes lenne megvizsgálni, hogy képes lenne-e egy hazai fejlesztésü rendszer hasonló módon jelentős erő- és eszközallokáció, idő- és hatékonyságmegtakarítást eredményezni. Ezenfelül további vizsgálat tárgyát képezheti, hogy e rendszer elemei átültethetők lennének-e katonai célú felhasználásba (például tüzérségi adatgyűjtési szakfeladatok - tűzmegfigyelés, tüztámogatás).

\section{Felhasznált irodalom}

$3^{\text {rd }}$ INSARAG Global Meeting 2020 Concept Note - INSARAG Session on Strategic Objectives 2020-2025. INSARAG website, 2019. Online: www.insarag.org/ wp-content/uploads/2016/04/Annex_E_INSARAG_Global_Meeting_2020_Concept_Note.pdf

Adler, David: The Mexico City earthquake, 30 years on: have the lessons been forgotten? The Guardian, 2015. szeptember 18. Online: www.theguardian.com/cities/2015/ sep/18/mexico-city-earthquake-30-years-lessons 
Hábermayer Tamás: Az Egyesült Nemzetek Szervezete (ENSZ) minősített városi...

BBC: In pictures: $25^{\text {th }}$ anniversary of Armenian earthquake. BBC News, 2013. Online: www.bbc.com/news/in-pictures-25262363

Hartner Péter - Hábermayer Tamás - Muhoray Árpád: A Globális Katasztrófa Előrejelző és Koordinációs, valamint a Közösségi Veszélyhelyzeti Kommunikációs és Információs Rendszerek bemutatása. Hadmérnök, 13. (2018), 3. 203-218.

Hábermayer Tamás: A Kobo Toolbox program alkalmazása az ENSZ INSARAG minősített mentőcsoportok kiterjedt kárterület felmérése során. Hadmérnök, 12. (2017), 2. 123-137.

INSARAG External Classification Handbook, Volume II Manual C, Annex A - The IEC/R checklist - UN INSARAG, 2019. Online: www.insarag.org/guidance-notes/ checklists/iec-2/

INSARAG: RDC, UCC, EXCON, Team Guide. INSARAG, 2020. Online: www.insarag. org/guidance-notes/manuals/information-management

INSARAG Technical After Action Review following Beirut port explosions 4-5 November 2020. UN INSARAG, 2020. Online: www.insarag.org/wp-content/uploads/2021/06/ AAR-Report_Final.pdf

Safi, Michael - Garry Blight - Lydia McMullan - Esther Opoku-Gyeni - Marina Costa Tala El-Issa: Beirut blast: a night of horror, captured by its victims. The Guardian, 2020. Online: www.theguardian.com/world/ng-interactive/2020/nov/12/beirutblast-a-night-of-horror-captured-by-its-victims

UN: „BSAFE” - United Nations Department of Safety and Security Online courses website. 2020. Online: https://training.dss.un.org/thematicarea/detail?id=19948 